\title{
The Effectiveness of Postpartum Exercise and Oxytocin Massage on Uterus Involution
}

\author{
Dian Nur Hadianti, Djudju Sriwenda \\ Poltekkes Kemenkes Bandung, Bandung City, Indonesia \\ Email: diannurhadianti80@gmail, sriw3nda@gmail.com
}

How to cite this paper: Hadianti, D.N. and Sriwenda, D. (2019) The Effectiveness of Postpartum Exercise and Oxytocin Massage on Uterus Involution. Open Journal of Nursing, 9, 231-238. https://doi.org/10.4236/ojn.2019.93023

Received: January 28, 2019

Accepted: March 4, 2019

Published: March 7, 2019

Copyright $\odot 2019$ by author(s) and Scientific Research Publishing Inc. This work is licensed under the Creative Commons Attribution International License (CC BY 4.0).

http://creativecommons.org/licenses/by/4.0/

(c) (i) Open Access

\begin{abstract}
The process of involution will work well if uterus contraction is strong, so a treatment can be done to improve uterus contraction. Postpartum exercise can make uterus muscles undergo contractions and retractions. In addition to pospartum exercise, being control of bleeding from the placenta attached is maintaining contraction and retraction fiber of strong myometrium through oxytocin massage. Purpose: This study aimed to ascertain influences of postpartum exercise and oxytocin massage on uterus involution. Method: The design used is quasi experimental research using post test only designing two comparison treatments. This research was conducted at PONED (basic emergency obstetric and neonatal care) in Bandung. The sample size was 50 respondents (25 respondents were given treatment for postpartum exercise and 25 respondents were given the oxytocin massage treatment). The sampling technique with non probability sampling techniques was by means of quota sampling. The data use primary data through the process of interview and observation. Deep data collection tool uses observation sheets and questionnaires. Result: The average uterus involution on the postpartum exercise group was 8.68 days, while the oxytocin massage group was 6.72 days. The results of the Mann Whitney Test statistic were at $95 \%$ confidence level; there was a significant difference in uterus involution between the postpartum exercise group and the oxytocin massage group with a value of $\mathrm{p}<0.001(\mathrm{p} \leq 0.05)$. Oxytocin massage is more influential to accelerate uterus involution. Conclusion: Oxytocin massage is more influential than pospartum exercise to uterus involution.
\end{abstract}

\section{Keywords}

Postpartum Exercise, Oxytocin Massage, Uterus Involution

\section{Introduction}

Uterus involution is the process transformed from pregnant to nonpregnant size 
[1]. If two weeks after giving birth the uterus has not yet entered the pelvis, it is necessary to suspect of being uterus subinvolution. Subinvolution is the failure of the uterus to return to not pregnant. The most frequent causes of subinvolution are the retention of fragments placenta, infection and advanced bleeding (late postpartum hemorrhage) [2].

The process of involution will work well if uterus contraction is strong, so a treatment can be done to improve uterus contraction [3]. One step to avoid subinvolution is by mobilizing and carrying out simple activities such as postpartum exercise. Postpartum exercise can make uterus muscles undergo contractions and retractions. Postpartum exercise can accelerate the return of muscle strain after it is done regularly, improve the strain of pelvic muscle and strain of the lower limb muscles and can reduce the scale of pain during the Postpartum [4]. Other research said that there is the influence of postpartum exercise to decrease in fundal height on postpartum [5].

In addition to pospartum exercise, being control of bleeding from the placenta attached is maintaining contraction and retraction fiber of strong myometrium through oxytocin massage. Oxytocin massage could stimulate the release of the oxytocin hormone which is an important part of the pospartum [6]. This is in line with the study of Khairani (2012) that there is an effect of oxytocin massage on continued involution in pospartum with $p=0.000(<0.05)$ [7]. Oxytosin massage is done by massaging the spine from neck until the fifth or the sixth costae to stimulate prolactin and oxytosin [8]. Oxytocin hormone stimulates uterus muscle contraction so that the uterus involution becomes faster and better. The process of involution will undergo well when the uterus contractions are strong, so it must take a treatment to improve uterus contractions [3].

Subinvolution can cause postpartum bleeding. According to the 2012 IDHS, the number of postpartum bleeding was $30.1 \%$. This was one of the causes of Maternal Mortality [5]. The purpose of this study was to determine the effect of postpartum exercise and oxytocin massage on uterine involution.

\section{Method}

\subsection{The Study Design}

The Study used is quasi experimental research using post test only design with two comparison treatments. This research was conducted at PONED (basic emergency obstetric and neonatal care) in Bandung. The sample size was 50 respondents (25 respondents were given treatment for postpartum exercise and 25 respondents were given the oxytocin massage treatment).

\subsection{Population and Sample}

The subjects were postpartum women with normal labor who fulfilled the inclusion criteria (Postpartum period 2 hours-10 days, women who breastfeed their babies and women who do not have systemic diseases), meanwhile the exclusion criteria are women who are not willing to be a respondent, women who got sick 
during the observation period and women who stop breastfeeding during the observation period. The sampling technique with non probability sampling techniques by means of quota sampling which samples are taken taking into account certain characteristics until the specified quota number is fulfilled. Determination of the samples uses the formula.

\subsection{Research Procedure}

The Study used primary data through the process of interview and observation. Deep data collection tool uses observation sheets and questionnaires.

The control group and intervention did not have socio-demographic differences. The study was conducted at PONED in Bandung with a socio-demographic background that was similar to one another.

Grouping of respondents is done in 4 different places according to the aim of considering research ethics. Respondents who undergo giving birth in PONED $\mathrm{A}$ and $\mathrm{B}$ were given postpartum exercise, while the others in PONED C and D were given oxytocin massage treatment. Data collection was carried out at 2 hours postpartum period up to 10 days or Uterus Fundus Height (UFH) was declared not palpable using the observation sheet.

Every respondent given an explanation of the benefits, objectives and actions that will be accepted and the action continued in their home. Each respondent who was willing to be asked to fill out informed consent. Before data collected, screening was carried out according to the terms of inclusion and exclusion. Women who have fulfilled the requirements are then observed. The first observation was carried out at 2 hours postpartum period that is examination of the UFH using the examiner's finger to determine the location of the fundus and uterus contractions. Subsequent examination of the UFH was carried out during the home visit from the $5^{\text {th }}$ day of the postpartum until the UFH was declared not palpable.

The control group (postpartum exercise) was taught and asked to do postpartum exercise for 10 minutes at 10 - 16 hours after giving birth. Furthermore, respondents were asked to do postpartum exercise at home at the same time as the first time they were taught, carried out every day until it was stated that the UFH was not palpable. Uterine Involution was carried out by the examiner by checking and recording the results of the UFH examination starting at 2 hours during the postpartum period, continued on the fifth day until the UFH was declared not palpable.

Postpartum exercise consists of warming up, core exercise and cooling down. Core exercises consist of breathing exercises, abdominal and pelvic floor exercises, leg exercises, good posture, exercise for restoring of elasticity and strength muscle of uterine.

The intervention group (oxytocin massage) was given by the examiner at 10 16 hours after delivery for the first time, then the husband or family will be taught the oxytocin massage technique and then he must perform on the res- 
pondent every day at the same time as the first massage oxytocin by the examiner. Oxytocin Massage is done until the UFH is declared not palpable.

Oxytocin Massage Technique is done by massaging, pressing and forming a small circular motion along both sides of the spine to 5 - 6 ribs using the thumb and fist.

\subsection{Data Analysis}

Data analysis used Mann Whitney Test statistic at 95\% confidence level. A p-value less than 0.05 is considered statistically significant

\section{Result}

Table 1 shows that most of the respondent's age is 20 - 35 years, as many as 35 people $(78.0 \%)$ have a high school education background of 25 people (50\%). Most respondent's parity were 2 - 3 as many as $54.0 \%$.

Table 2 shows that the average gestational age is 38.86 weeks. The average baby weight is 3093 gram, while for the average breastfeeding frequency is 10.7 times, while the average uterus involution is 7.70 days.

Table 1. Overview of respondent characteristics.

\begin{tabular}{|c|c|c|}
\hline Variable & $\mathrm{N}$ & $\%$ \\
\hline \multicolumn{3}{|l|}{ Age (years) } \\
\hline$<20$ years old & 3 & 6.0 \\
\hline 20 - 35 years old & 39 & 78.0 \\
\hline$>35$ years old & 8 & 16.0 \\
\hline \multicolumn{3}{|l|}{ Education } \\
\hline Elementary school & 2 & 4.0 \\
\hline Junior high school & 18 & 36.0 \\
\hline Senior high school & 25 & 50.0 \\
\hline University & 5 & 10.0 \\
\hline \multicolumn{3}{|l|}{ Parity } \\
\hline 1 & 13 & 26.0 \\
\hline $2-3$ & 27 & 54.0 \\
\hline$\geq 4$ & 10 & 20.0 \\
\hline
\end{tabular}

Table 2. Overview respondents by gestational age, baby weight, breastfeeding frequency and uterus involution.

\begin{tabular}{cccc}
\hline Variable & Average & Median & Stand of Dev. \\
Gestational age & 38.86 week & $39.00 \mathrm{wks}$ & 1.06 \\
Baby weight & $3093.80 \mathrm{gr}$ & $3095.00 \mathrm{gr}$ & 319.00 \\
Breastfeeding frequency & 10.70 & 10.00 & 2.25 \\
Uterus involution & 7.70 & 8.00 & 1.85 \\
\hline
\end{tabular}


From Table 3 it could be seen that average of uterus involution on the postpartum exercise group was 8.68 days, while the oxytocin massage was 6.72 days, that there was a significant difference in uterus involution between the postpartum exercise group and the oxytocin massage group with value $\mathrm{p}<0.001$ ( $\mathrm{p}<$ $0.05)$. Oxytocin massage is more influential to accelerate uterus involution.

\section{Discussion}

The progress of involution can be measured by assessing the height and consistency of the uterus. Fundus can arise immediately after labor and on the first day after partum, but then drop by about $1 \mathrm{~cm}$ or one finger every day. Uterus keep in the middle of the line approximately $2 \mathrm{~cm}$ were taken umbilicus with fundus part rests on sacred promontory. Within 12 hours, the UFH reached less more than $1 \mathrm{~cm}$ above the umbilicus. Within a few days, changes in involution take place quickly [6].

Uterus involution could be influenced by several factors, one of which is early mobilization or postpartum exercise, so that uterus contractions will be good so that the uterus fundal is hard, so the risk of abnormal bleeding can be avoided. [9]

In this study, uterus involution is approximately 8.7 days in women who do postpartum exercise. This is in accordance with the opinion of Surtiati and Nawati (2010) who stated that postpartum exercise done by postpartum women had effected to physical recovery, including uterus involution 9 times better in women who were not given postpartum exercise [10]. According to Masruroh (2012), it shows that influence postpartum exercise with a high decrease in uterus fundus [11]. Runnilyl et al. (2014) that postpartum exercise affects the decrease in UFH and strengthens uterus muscle contractions [12]. The physiological effect of oxytocin massage is to stimulate contractions of the smooth muscle of the uterus, both during and after labor so that it can accelerate the process of uterus involution. The process of involution will do well if the uterus contractions are strong, so it must be taken to improve uterus contractions [3].

In this study, the average uterus involution that occurred in the group of women who undergo oxytocin massage occurred for 6.7 days. This is consistent with Khairani et al. (2012) found that oxytocin massage had an effect of uterus involution on postpartum women at Hasan Sadikin Hospital in Bandung [7]. The effect of oxytocin massage on uterus involution in Sukoharjo General Hospital [13].

Table 3. The effect of postpartum exercise and oxytocin massage on uterus involution.

\begin{tabular}{|c|c|c|c|c|c|}
\hline \multirow{2}{*}{ Group } & \multicolumn{4}{|c|}{ Uterus involution (days) } & \multirow{2}{*}{$\mathrm{p}$ value } \\
\hline & Average (SD) & Median & Min & Max & \\
\hline Postpartum exercise & $8.68(1.57)$ & 9 & 6 & 14 & \multirow{2}{*}{$<0.001$} \\
\hline Oxytocin massage & $6.72(1.59)$ & 7 & 5 & 10 & \\
\hline
\end{tabular}

Mann Whitney Test. 
Doing postpartum exercise and oxytocin massage will cause uterus involution to run well. In this study oxytocin massage had more effect on uterus involution compared with postpartum exercise. This research is reinforced by a theory revealed by Pillitery (2003) that oxytocin massage can stimulate the anterior pituitary and posterior to secrete the oxytocin hormone. The oxytocin hormone will trigger contraction of smooth muscle in the uterus so that uterus involution will occur, while the sign of oxytocin reflex is the presence of pain due to uterus contractions [14]. The above theory is in line with this study, which is strong uterus contractions as a result of oxytocin massage interventions.

Oxytocin is a hormone that can increase the entry of calcium ions into the intracellular. The release of the oxytocin hormone will strengthen the act in and myosin bonds, so that the uterus contractions get stronger and the process of uterus involution is getting better [3]. Uterus involution can be influenced by several factors, including lactation, early mobilization or postpartum exercise, nutrition, parity, psychological and maternal age. The age very closely related to the decrease in height of the uterus fundus in postpartum women. The older of someone's age as the less reproductive function, which is found in an average age of more than 35 years. Along with increasing age, the elasticity of the muscles of the reproductive organs also decreases. The maternal age affects the muscle elasticity of the uterus, at the age of 35 years and more, the muscle elasticity decreases [15]. Women who are older are much influenced by the aging process, where the aging process increases the amount of fat. Decreased muscle elasticity and decreased absorption of fat, protein, and carbohydrates. If this process is associated with a decrease in protein in the aging process, this will inhibit uterus involution [2].

Breastfeeding is one of the factors that influence the process of involution; it is known that in the postpartum period, the internal and external genitalia organ will gradually recover as before pregnancy [3]. After giving birth, the effect of pressure from estrogen and progesterone on the pituitary is lost,so that the influence of the pituitary hormone arises, including LH (Lactogenic Hormones, the effect of oxytocin results in my oepithelial mammary glands contracting, so that breast milk production occurs).

Oxytocin, estrogen and prostaglandins work as astimulator in providing a strong stimulus to the myometrium to contract, so that due to the collapse of the endometrial cells and mixed with uterus secretions produced by the glandular cells of the endometrium. The ongoing process of rhythmic contraction followed by the release of collapsed endometrial cells and postpartum secretion of uterus fluid causes the release of lochea. The volume and condition of the nulliparous blood vessel pores is greater so that the process of removing lochea is faster than that of primipara. The results of the study revealed that maternal parity affects the length of time spent by lochea, the higher the parity the faster the expenditure process for lochea. However, because the condition of the uterus muscles in multipara maternity women tends to be not too strong, the process of involution 
runs more slowly.

Psychical stimulation is a reflex from the women's eye to the brain that produces oxytocin, so that breast milk could be released and as a side effect the uterus becomes harder to contract. Oxytocin causes contraction and retraction of the uterus muscles so that it will suppress blood vessels resulting in reduced blood supply to the uterus which helps reduce bleeding.

\section{Conclusions}

Oxytocin massage is more influential than postpartum exercise to uterus involution. Therefore, it is expected that health professionals, specifically midwives, should implement and teach the families of postpartum women to do oxytocin massage.

There are limitations of the study. Researchers could not observe the postpartum exercise and oxytocin massage at the client's house every day or just only several times. Some were monitored by telephone every day.

\section{Conflicts of Interest}

The authors declare no conflicts of interest regarding the publication of this paper.

\section{References}

[1] Reeder, et al. (2004) Keperawatan Maternitas: Kesehatan Wanita, Bayi dan Keluarga V/2 E/18. EGC, Jakarta.

[2] Maryunani, A. (2009) Asuhanpada Ibudalam Masa Nifas (Postpartum). Trans Info Media, Jakarta.

[3] Cunningham, F.G., Donald, P.C., Mc Gant, N.F., Alih, B, Joko, S. and Andri, H. (2013) Obstetri William. 21st Edition, EGC, Jakarta, Vol. 2.

[4] Smith-Hay, et al. (2009) Pelvic Floor Muscle Training for Prevention and Treatment of Urinary and Faecal Incontinence in Antenatal and Postnatal Women (Review). The Cochrane Collaboration.

[5] Fadlina (2015) Pengaruh Senam Nifas terhadap Penurunan Tinggi Fundus Uteri pada Ibu Post Partum. Fakultas Ilmu Kesehatan Universitas Muhamadiyah Surakarta

[6] Bobak, D. (2004) Buku Ajar Keperawatan Maternitas. EGC, Jakarta.

[7] Khairani, D. (2012) Pengaruh Pijat Oksitosin Terhadap Involusi Uterus Pada IbuPost Partum Di Ruang Post Partum Kelas IIIRSHS Bandung. Fakultas Ilmu Keperawatan Universitas Padjadjaran.

[8] Roesli, U. (2009) Inisiasi Menyusu Dini dan ASI ekslusif. Pustaka Bunda, Jakarta.

[9] Ambarwati dan Wulandari (2008) Asuhan Kebidanan Nifas. Mitra Cendikia, Yogyakarta.

[10] Surtiati and Nawati (2010) Pengaruh senam nifas terhadap pemulihan fisik ibu pospartum spontan di Rumah Sakit PMI dan Salak Kota Bogor. Risbinakes Poltekkes Bandung, Bandung.

[11] Masruroh (2012) Pengaruh Senam Nifas terhadap penurunan Tinggi Fundus Uteri pada ibu Post Partum. Prosiding, 1, 1-5. 
http://journal.unipdu.ac.id:8080/index.php/seminas/article/view/164/111

[12] Rullynil (2014) Pengaruh Senam Nifas terhadap Penurunan Tingi Fundus Uteri pada ibu Post Partum di RSUP DR. M. Djamil Padang. Jurnal Kesehatan Andalas, 3, 318-326. http://jurnal.fk.unand.ac.id

[13] Sartika (2015) Pemberian pijat Oksitosin Terhadap Involusi Uterus Pada asuhan keperawatanPost Partum Ny. M di ruang bougenvile RSUD Sukoharjo. Surakarta

[14] Pillitery (2003) Maternal and Child Health Nursing. Buku I. 4th Edition, Lippincott, Philadelphia.

[15] Liana (2013) Faktor-faktor yang mempengaruhi tinggi fundus uterus pada ibu post partum di Rumah Sakit Banda Aceh, STIKES U’Budiyah Acidin Banda Aceh. 